This essay offers an examination of Agamben's statement that there is an important ambiguity in Aristotle's Metaphysics Theta as to whether actuality or potentiality is primary. I argue that this ambiguity is significant because it exposes the ontological dimension of Agamben's paradox of sovereignty.

\title{
The Modality of Sovereignty: Agamben and the Aporia of Primacy in Aristotle's Metaphysics Theta
}

NAHUM BROWN

D otentiality and Law" is one of the more important chapters of Homo Sacer because this is where Agamben exposes the ontological dimension of his political theory of sovereignty, bare life, and the production of homo sacer. In Giorgio Agamben: A Critical Introduction, Leland de la Durantaye calls "Potentiality and Law" a "lacunae" in the literature on Agamben (229). My aim in this study is to contribute to the literature that will fill this "lacunae." I limit the scope of this essay primarily to an analysis of subdivision 3.3 of "Potentiality and Law." Here, Agamben discusses Aristotle's Metaphysics Theta and posits an analogy between the political paradox of sovereignty and an ontological modal paradox, which Agamben attributes to Aristotle's various accounts of the circular primacy between actuality (energeia) and potentiality (dynamis).

This essay is a monograph of one statement by Agamben about Aristotle: "If it is never clear, to a reader freed from the prejudices of tradition, whether Book Theta of 
the Metaphysics in fact gives primacy to actuality or to potentiality, this is not because of a certain indecisiveness or, worse, contradiction in the philosopher's thought but because potentiality and actuality are simply the two faces of the sovereign selfgrounding of Being" (47). While there have been a number of studies closely related to this theme, none has directly addressed the paradox of sovereignty in the terms of the ontological paradox that Agamben finds in Aristotle's Metaphysics Theta. ${ }^{1}$

My strategy is to establish the two arguments separately: on the one side that actuality is more primary than potentiality, but on the other side that potentiality is more primary than actuality. Although of these two arguments Agamben often supports the potential not-to-be as the more decisive mode, ${ }^{2}$ my aim is to establish the undecidability of these arguments and claim that this modal paradox (that actuality and potentiality are both more primary) underlies the paradox of sovereignty. While Agamben does not explicitly establish each argument separately, he suggests such a project when he says that it should never be clear to the reader of Book Theta whether actuality or potentiality precedes. ${ }^{3}$ He suggests such a project when he writes, "according to Aristotle's thought, potentiality precedes actuality and conditions it, but also seems to remain essentially subordinate to it" (44).

One might object, based on the quote above, that when he says "potentiality and actuality are simply the two faces of the sovereign self-grounding of Being," Agamben no longer has the sovereign paradox in mind. On my reading, "the self-grounding of Being" is the ontological version of the political paradox. Agamben explains this quite clearly in the first sentence of Chapter 3.1: "Nowhere else does the paradox of sovereignty show itself so fully as in the problem of constituting power and its relation to constituted power" (39). The sovereign paradox is not the sort of paradox that becomes resolved in the political, as certain paradoxes are solvable or avoidable. Agamben's point is that the political paradox persists and gains its full expression as "the self-grounding of Being," as a constitutive ontological paradox, which at the same time underlies the political and grounds it.

Taken together, the aporia that actuality and potentiality are both the more primary ontological category creates the paradoxical position of the actuality of what was supposed to be impotentiality. Agamben describes this modal paradox as the existence of what cannot exist, and as the removal of existence from life. The sovereign, who declares from outside the law that there is nothing outside the law (15), and the homo sacer, who can be killed but cannot be sacrificed (83), are the two political ramifications of this modal paradox. The sovereign is the actuality of impotentiality because the sovereign authorizes (and equally is authorized by) the law through exception, by subsuming the exteriority of the law within its own legal framework, 
and thereby re-founding the border of the law without ever transgressing it. The homo sacer, as the parallel opposite of the sovereign, also exemplifies the actuality of impotentiality, but in the sense that the homo sacer is the living actuality of what cannot be, the existence of what cannot exist. Agamben also sees in the logical structure of the modal aporia not only the paradox of sovereignty, but also the optimism of an affirmative politics, wherein potentiality no longer has any relation to actuality. While his project of an affirmative politics is beyond the scope of this essay, I will allude to why Agamben claims that such a politics could extend from the logic of the paradox. ${ }^{4}$

Agamben begins Homo Sacer from a particular reading of Aristotle's Politics. Where Aristotle famously defines the human as the only animal whose phusis is logos and whose basic life is the "politically qualified life," Agamben reads into this not only a distinction between $z o \bar{e}$ and bios, that is, between bare life and political life, but moreover the implication of zoe into bios (7), that is, the inclusion of bare life in the polis. On its own, Agamben's reading of zoe and bios as a primary topic in the Politics is controversial enough. ${ }^{5}$ Agamben finds in the distinction not only an opposition, but the problematic inclusion through exclusion of $z o \bar{e}$ in the polis that ultimately develops into a "zone of irreducible indistinction" (9). The thesis of Homo Sacer begins from the premise that although the Ancients also realized the inclusion of $z o \bar{e}$ in the polis, only in modernity does this inclusion become paradoxically "indistinct."

The topological structure of this zone of indistinction has its basis in the figure of the sovereign, who is both outside and inside the juridical order. Agamben develops this concept of sovereignty from Carl Schmitt's Political Theology (5). Since the sovereign can initiate a state of exception, the sovereign paradox takes the form both that "the law is outside itself" and that the sovereign never reaches the outside of the law (15). The sovereign is indistinguishably outside and inside the juridical order because the power of the state of exception is both precisely an exception to the law and at the same time the limit or principle of the law.

It would seem evident that if the sovereign's exception is an exception to the law, the law itself, then, necessarily precedes the exception, and the juridical order necessarily precedes the sovereign. But Agamben claims that the sovereign also precedes the juridical order because the law only comes into being through the exception. Thus, the sovereign paradox takes the further form both that the law is the origin of the exception and that the exception is the origin of the law. This becomes, for Agamben, "the relation of exception" (18). What is excluded remains included by negative relation within the space or membership of what is enacting the exclusion.

Life exists at this threshold, indistinguishably outside and inside the law. Zo $\bar{e}$ is indistinguishably included in the polis through the enactment of its exclusion from 
the polis. When Agamben states, "law refers to life and includes it in itself by suspending it" (28), this is the paradox of the sovereign: that through exception, law both produces life and abandons it. Agamben then turns from the political dimensions of this problem, which he finds in Aristotle's Politics, to the ontological dimensions of this problem, which he finds in Metaphysics Theta. The indistinction between life and law, between $z o \bar{e}$ and bios, has as its ontological foundation the indistinction between whether actuality or potentiality is the more primary category. The ontological dimension of this indistinction comes from the Aristotelian insight that dynamis is "always also dynamis me energein, the potentiality not to pass into actuality" (28); in other words, that potentiality is always both the potential only to be actuality (actuality precedes) and equally the potential not to be actuality (potentiality precedes). To understand how the ontological dimension underlies the political, it is necessary to examine Agamben's reading of Aristotle's Metaphysics Theta as the constitutive ambiguity of the primacy of actuality and potentiality.

$\mathrm{T}$ he first argument is that actuality is more primary. In division 8 of Metaphysics Theta, Aristotle says that actuality is prior to potentiality in terms of account or definition (logos) and in terms of substance (ousia), and that it is prior in one sense and posterior in another sense in terms of time (chronos). Actuality is prior in account because knowledge of the potential presupposes knowledge of the actual. Aristotle explains that to have the capacity to build is the potential of the actual builder: "I mean by 'capable of building' that which can build, and by 'capable of seeing' that which can see, and by 'visible' that which can be seen" (1049b: 14-16). Actuality is prior in terms of substance because actuality is the end or goal of potentiality. Just as what is in a state of becoming naturally moves toward the full maturity of its form, likewise potentiality is the state of movement or change toward the goal of actuality. Actuality, then, is the principle of potentiality; it is that which potentiality intends to be; it is the teleological goal of potentiality. Aristotle gives the example of how animals see: "animals do not see in order that they may have sight, but they have sight that they may see" (1050a: 10-11). In terms of time, actuality is posterior in the sense that immaturity is the point-of-beginning and maturity is what the immature moves toward. But actuality is still prior to potentiality both in the sense of species-for example, the parent precedes the child (1049b: 24-26) — and in the sense that a capacity is impossible if time is not spent to acquire the capacity. Aristotle gives the example of the harpist: "this is why it is thought impossible to be a harpist if one has never played the harp; for he who learns to play the harp learns to play it by playing it" (1049b: 30-32). 
Traditionally, interpreters of Aristotle's Metaphysics Theta tend to conclude from this that although potentiality exists, actuality is the more primary category. In his commentary Aristotle Metaphysics Book $\Theta$, Stephen Makin claims that the conclusion "actuality is prior in substance to potentiality" is one of the most important results of Metaphysics Theta (181). In Ways of Being, Charlotte Witt devotes an entire chapter to the priority of actuality (75-96). When Aristotle says that actuality is more primary than potentiality, he means that potentiality exists for the sake of actuality, that potentiality is always either actualized or actualizable potential. Potentiality is really only the movement or change from actuality to actuality. More than just the sense that one is more prior than the other, actuality covers potentiality over and makes it its own. Potentiality exists, but it exists only as actuality. Even the most abstract sense of potentiality, one that is fleeting and never becomes actual, even mere possibility that never occurs, still gives an account, in one way or another, of what it would have meant to be actual.

Aristotle's theory at division 8 , that actuality is prior to potentiality, comes in part from his definition at Theta division 1, that potentiality is "a source of change" in the actual (1046a: 9-11). Here, Aristotle lists a complicated set of relationships between actuality and potentiality. In terms of agency, a thing can be said to change itself or change an other. A thing can also be a passive agent, having the power to be changed by an other, or by itself as other (for example, a pair of eyeglasses has the passive power to be broken by the hammer.) In terms of resistance, a thing can be said to sustain itself in the face of change, and this again in all four senses, as when something sustains itself against another, or against itself, or when something has the power to let an other sustain itself, either as other or as itself. In terms of privation, a thing can be said to lack the power to change, either because it naturally does not have this power or because it lacks the ability that by its own nature it should have had. A snail, for example, does not have the natural ability to swallow a whole adult rhinoceros. Likewise, a person who is blind has lost the ability to see, and a thing that has become invisible lacks the ability to be seen. The complexities of these variations from division 1 help to illustrate Aristotle's point, that potentiality is only the movement or change from activity to activity, and that since it is just move-ability or change-ability, potentiality depends upon what is moved, the actual, for its existence.

However, Aristotle does maintain that although it is only an account of the movement between actuality, potentiality nevertheless exists. We should thus be careful to distinguish the Aristotelian argument, that potentiality exists only as a source of change in the actual, from the Megarian argument, that potentiality simply does not exist and that actuality is all there is. Whereas the Megarians assert that all being is actual and that there is nothing but being, Aristotle maintains, on the contrary, that 
potentiality must exist, in one way as being, in another way beyond being; otherwise, there would be no way to explain why a thing has the ability to change, either into what it is not, or into another sense of what it is. ${ }^{7}$ Otherwise, the builder would lose the ability to build whenever she is not in the act of building, which is absurd. In Aristotle's words, from division 3, the Megarians believe that "a thing can act only when it is acting, and when it is not acting it cannot act, e.g. he who is not building cannot build, but only he who is building, when he is building" (1046b: 29-31). If what the Megarians say were true, there would be no explanation for the movement from one state of actuality to another. In a world without potentiality, there would be no way to begin to move, no way to end, and no way to change.

Absurdities aside, the Megarian's position is quite significant for Aristotle's modal project, as it is for Agamben's paradox of the sovereign, because the Megarian's position accentuates a certain necessary and non-retractable bind between actuality and being, which effectively marginalizes the role of potentiality. By articulating the most extreme version of this insight, that actuality and being are bound to one another, and that really potentiality cannot be, the Megarians have attempted to avoid a complicated problematic: potentiality exists and yet its existence is only the existence of actuality. The Aristotelian argument, rather than avoiding or resolving this paradox, is rather the full expression of the paradox. Potentiality must exist; and yet to expose this existence is to expose the existence of actuality. In this sense, the claim that potentiality exists, and the claim that potentiality is always only actuality, are one and the same claim. This is the case because any account of what potentiality is presupposes an account of its actuality. Potentiality exists, which means that what is potential is only a potentiality of what is actual. In other words, the resources of the second argument, that potentiality is the more primary category, are contained in the juxtaposition that potentiality exists, on the one hand, but that its existence, on the other hand, is only the existence of actuality.

T he second argument is that potentiality is more primary. When Agamben says that Aristotelian potentiality is also more primary than actuality, he does not base this claim on the one sense that potentiality is prior to actuality in terms of time, as in the sense that the immature body precedes the mature body; he bases it, rather, on the claim that the potentiality to be is equally the potentiality not to be. Agamben's point is that if we are to maintain that potentiality exists, as Aristotle does against the Megarians, then we will need to secure a pure potentiality that does not pass over into actuality. Agamben argues that potentiality exceeds actuality when he writes, "if potentiality is to have its own consistency and not always disappear immediately into 
actuality, it is necessary that potentiality be able not to pass over into actuality, that potentiality constitutively be the potentiality not to (do or be), or, as Aristotle says, that potentiality be also im-potentiality (adynamia)" (45).

Whereas the first argument begins from the premise that potentiality is always only the potentiality to be actuality, the second argument begins from the premise that, since the potentiality to be equally posits the potentiality not to be, the existence of potentiality must also have a pure place of its own, one that is independent of actuality. The second argument begins from the premise that potentiality is as open to its own non-being as it is to its actuality. When we emphasize that potentiality is only the potentiality to be, as per the first argument, we develop the resources for the traditional conjunction of potentiality and actuality as the hegemony of actuality; then potentiality disappears into actuality; then the existence of potentiality is only the existence of actuality. But when we emphasize that potentiality is also the potentiality not to be, then we both give potentiality a position that is independent of actuality and we create an argument for why potentiality is more primary than actuality.

As textual evidence for the second argument, Agamben refers to two sentences from Metaphysics Theta. 1) "Every potentiality is impotentiality of the same and with respect to the same," and 2) "what is potential can both be and not be. For the same is potential as much with respect to being as to not being" (45). For Aristotle, the nature of potentiality is such that it is as open to the contrary position of its actuality as it is to its existence as actuality. This openness to the contrary of the actual is not only an openness to another actual that is in opposition to the first, but also to the existence of a potentiality that is non-actuality.

If we concede, for example, that the builder has the potential to build even when the builder is not in the act of building, then we have posited the equal potential that the builder will not build, since the whole notion of potentiality is that it remain open to the contingency that what can happen also can not happen. The actuality that the builder does build is just the fulfillment of the potential, by way of removing the equal potential that the builder could not have built. Agamben's point is that the removal of the potential not to be is the constitutive basis of actuality's existence. In this way, the concept of impotentiality is prior to the actualization of any potentiality. If something is of impotentiality, then it cannot both be and not be. But this means that actuality exists only by removing the impotentiality of what would otherwise be the contradiction of potentiality, that what is of potential both exists and does not exist. When we remove the impotentiality, the contradiction does not simply fall away, as if the impotentiality were inconsequential. Agamben maintains, to the contrary, that the removal of the impotential is the essence of the bind between actuality and being. "A 
thing is said to be potential," Aristotle writes, "if, when the act of which it is said to be potential is realized, there will be nothing impotential" (45). This sentence is crucial to Agamben's argument that potentiality is prior to actuality, not because it shows, as a tautology would, that something is actual merely if there is nothing impotential. Rather, if the removal of the impotential is the first condition of actuality's existence, this means that the actuality that is depends upon the potentiality not to be.

$\mathbf{P}$ ure potentiality and pure actuality," Agamben writes, "are indistinguishable, and the sovereign is precisely this zone of indistinction" (47). On the one hand, pure potentiality is really only actuality; it just folds and disappears; potentiality just dissolves into the being of actuality. Any statement such as that potentiality is $p$ is a statement about the disappearance of potentiality into actuality. To say that potentiality exists is to say that it is actuality. After all, how can one ever think the existence of what does not exist? To think the existence of what does not exist is precisely the impossibility of actuality, which causes the removal or disappearance of pure potentiality into pure actuality. On the other hand, it is only the removal of pure potentiality that causes an indistinguishability between actuality and potentiality and that determines actuality as existence. How can one ever think the existence of what does not exist? This question just as certainly reveals the priority of potentiality over actuality. In "On Potentiality," Agamben shows the existence and priority of potentiality when he asks this question in terms of vision, light, and darkness: "If potentiality were, for example, only the potentiality for vision and if it existed only as such in the actuality of light, we could never experience darkness (nor hear silence, in the case of the potentiality to hear). But human beings can, instead, see shadows (to skotos), they can experience darkness: they have the potential not to see, the possibility of privation" (181).

Darkness is supposed to be the privation of vision, the total absence of light. Then how can we see darkness? How can darkness be? Agamben's answer is that we see darkness because the potentiality not to be exists. Actuality, which is supposed to be synonymous with the verb to be, indeed depends upon the process by which it cancels out the potential not to be. Darkness then is an actuality by way of removing the potential not to be of the privation of vision. Darkness then is privation as actuality, the existence of the potential not to be.

When we juxtapose the primacy of the two arguments, we establish the existence of what does not exist, the potentiality of darkness; we see the privation of vision itself not only as the privation of the ability to see, but also as the actuality of this impotentiality. Actuality, remember, is supposed to be the removal of the potentiality not to be. Otherwise, the existence of both to be and not to be would be the existence of 
impotentiality as contradiction. Actualization removes the negative side of potentiality so that what is can exist. But when we say that actualization is the removal of the negative side of potentiality, we mean this as a dependent process: the actual only exists if the potential that it not be is removed and does not exist. In this sense, actuality is only a determinate existent insofar as the potentiality that it could not have been stands against it as its limit, as the outside beyond actuality. However, if that which exists outside and beyond actuality were to really exist in the way that actuality does, then the potentiality not to be would itself be an existent actual. But this would change the status of the impotential to the status of the actual. If the outside were itself an actual existent, we would have effectively removed the impotentiality from the impotentiality. But then the outside that constitutes the actual would not truly be an outside, but rather the inside of another actual. Since the impotential must sustain its position as an outside that is beyond actuality and really cannot exist, the potentiality not to be remains an outside that will never come. Herein lies Agamben's ontological paradox: the potentiality not to be is both the outside in the sense that it constitutes by contrast the inside of actuality, and yet the potentiality not to be is also the outside that will never come, in the sense that it only exists if the actuality subsumes its status within its own interiority. But then, when actuality subsumes its exteriority within itself, the potentiality not to be becomes the actuality of what is. This means that the potentiality not to be still does not exist, and yet, at the same time, it has become consummated by the interiority of actuality, and exists where it has no place.

Agamben's goal in Chapter 3, "Potentiality and Law," is to present this ontological, modal paradox as the structural foundation of the sovereign paradox. By subsuming the exteriority of transgression within the interiority of the law, the sovereign exploits the modal dimension in terms of the political. The sovereign paradox is thus the political expression of the modal, that potentiality determines actuality by the limits that are left as marks when the impotentiality is removed. The sovereign exception to the law subsumes within the official rights of the law what was supposed to be beyond the law as a transgression of the law. Such an exception is equivalent to the actualization of the potential not to be. Since the actuality of potentiality, as per actuality's priority, is always only in terms of the potentiality to be, which exists by way of removing the potential not to be, the sovereign exception moves the boundary or limit of the law without ever transgressing the law. The sovereign is the one who can never transgress the law, since the limit of the law is always equal to the sovereign's own declaration of what the law is. The homo sacer, as the exact opposite of the sovereign, is the one who has become trapped in the impossible exteriority beyond the law. Just as the sovereign cannot transgress the law, it is impossible for the homo sacer to belong 
to the earth and to have legal rights. In a sense, the homo sacer does not exist. A person who is not a person, the homo sacer cannot be sacrificed or murdered because it would need to exist as a legal citizen for the sacrifice to have any consequence, or for the murder to be a breach of the law. However, since it is the existence of what does not exist, the homo sacer can be killed, of course, but to kill it is a (non) act that has no effect. In this way, the homo sacer is the political expression of the abyss of potentiality, of an existence that remains in excess of actuality, even though the potentiality not to be cannot be. The modal paradox generates both sovereignty and the (non) existence of the homo sacer by subsuming the exteriority of the law within the legal boundaries of the law. By this subsumption of the exteriority, there is nothing outside the law. This "nothing" is the homo sacer.

The concentration camp becomes the exemplary (non) place for the existence of what cannot exist. Whereas in the classical model of sovereignty, the sovereign is a person who makes exceptions to the law and thereby opens the abyss of the homo sacer, in the contemporary model, the sovereign becomes the camp itself, a place as much as a person, and the homo sacer becomes an abyss that can open, not just for the sovereign's select individuals or groups, but for all of us en masse. Ironically, as Arendt demonstrates in the Origins of Totalitarianism, and Agamben reiterates in part three of Homo Sacer (126-35), the contemporary model of sovereignty can only develop once the rights of all citizens have become completely inalienable, as with the Declaration of the Rights of Man at the end of the eighteenth century. "Only with a completely organized humanity," Arendt writes, "could the loss of home and political status become identical with expulsion from humanity altogether" (290). The camp becomes the political expression of an actuality of what cannot be only when the political rights of the citizen have become attributed to the birth of every human body. The camp appears only when there is no way to alienate the human body from political rights. Then the sovereign exception to these inalienable rights casts the human, not only from the local political sphere, but beyond the earth itself and beyond all existence. The homo sacer becomes the existence of what does not exist, the actuality of impotentiality.

$\mathrm{T}$ he ambiguity of whether actuality or potentiality is more primary underlies the sovereign paradox, but Agamben also anticipates a new ontology of potentiality at the same source of this ambiguity. This new ontology could be a fundamental reconception of politics and of a social organization beyond the sovereign paradox. Just as potentiality is both the potential to be and not to be, the ambiguity of modal priority is both the source of the (im)potentiality of the concentration camps and at the same time the promise of political life beyond the sovereign/homo sacer dichotomy. 
In "On Potentiality," Agamben argues that human beings are different from other life because they are capable of the act, not only of the potentiality to be, but also of the potentiality of impotentiality: "Other living beings are capable only of their specific potentiality; they can only do this or that. But human beings are the animals who are capable of their own impotentiality. The greatness of human potentiality is measured by the abyss of human impotentiality" (182).

Human beings are different from other life because they recognize the existence of potentiality. The existence of potentiality is both the existence of darkness and light. Potentiality is the source, then, of both human excellence and at the same time the abyss of the can not. This is, no doubt, what Aristotle means when he calls humans the animals who give an account, whose phusis is logos. Humans are the ones who can give an account of the existence of potentiality, but this comes at the greatest of risks. On the one hand, by giving an account of the existence of potentiality, they can make an actuality of what should be impossible, such as the sovereign's state of (non) exception, the camp as a (non) place beyond the earth, and the homo sacer's (non) existence in the camp. But as the ones who can give an account of potentiality, they can also generate, on the other hand, a political dimension beyond the authority of actuality altogether. Agamben says this in "Potentiality and Law" when he writes: "One must think the existence of potentiality without any relation to Being in the form of actuality - not even in the extreme form of the ban and the potentiality not to be" (47). As the ones who can give an account, humans face the most difficult of tasks: to think a bind between potentiality and existence (to think the existence of potentiality) that is neither an actuality of potentiality nor an actuality of the potentiality not to be. This is precisely Agamben's project of an affirmative politics, to think potentiality beyond any relation to actuality whatsoever, to think the political beyond the sovereign ban.

However, in "Potentiality and Law," Agamben only alludes to the promise of a new ontology of potentiality, stating that such a conception of potentiality beyond the authority of the sovereign ban is either difficult or impossible in our contemporary age. Still there exist "significant attempts" to circumvent and undermine political exploitation of the modal ambiguity, and thereby to think the limit of the sovereign paradox. For Agamben, Melville's "Bartleby the Scrivener" is the best example of an attempt to expose the limit of the logical and topological structure of sovereignty. ${ }^{8}$ There is an important difference between the way the sovereign suspends all actuality by actualizing the potentiality not to be and the way Bartleby undermines the bind between being and sovereignty with the execution of the "I would prefer not to." By saying "I would prefer not to" rather than "I will not" or "I cannot," Bartleby effectively circumvents the authority of the narrator. The "I would prefer not to" acts as a suspension of a different 
sort than that of sovereignty. It is the suspension of the decision between the potentiality to be and the potentiality not to be. If Bartleby simply declared "I will not write" or "I cannot quit these law offices," this would not undermine the bind between being and sovereignty, since the "will not" and the "cannot" would re-inscribe Bartleby within the traditional modal conjunctions. But to say "I would prefer not to," although it does not release Bartleby from the sovereign ban, nevertheless circumvents the authority of sovereignty, since it is undecidability. It is not an actualization of the potentiality not to be in the way of sovereignty. The potentiality not to be is affected, rather, through the strategy of an undecidability to be and not to be.

I will conclude with what I believe is another significant attempt to think beyond being and sovereignty, an example that is historical rather than fictional, one which comes from Arendt rather than from Melville. Just as Bartleby exposes the undecidability between the potentiality to be and the potentiality not to be, so did Denmark expose a similar tactic of undecidability as a way to circumvent Eichmann and the Nazis during World War II. In her book Eichmann in Jerusalem, Arendt outlines the various ways each major European country responded to Eichmann's demand that Jewish citizens become denationalized and eventually be transported to the camps. Some countries, such as Romania, zealously carried out the Nazis' program. But other countries, Denmark in particular, undermined the Nazis' authority (171-73). When Eichmann demanded that all Jews wear the Star of David so as to isolate them in preparation for complete denationalization, all Danish citizens, not only the Jews, wore the star, which effectively circumvented the segregation process. In this sense, Denmark employed the strategy of undecidability. If the Danish had said "I will not give over the Jews," this "I will not" would have created an authoritative opposition, which no doubt would have instigated Nazi force. But by withholding the decision of whether they would or would not comply with the demands, the Danish exposed the limits of the Nazis' authority and effectively opposed this authority, not with an oppositional authority, but rather with an affect of undecidability. These examples of how to expose the limits of the sovereign paradox remain a product of the ontological paradox of modality; still, Agamben sees in them the promise of a new ontology of potentiality that not only exposes the limits of the sovereign, but could establish a political structure beyond these limits.

\section{NOTES}

1/ In "The King of the Cosmos: Potentiality, Actuality, and the Logic of Sovereignty in Aristotle's Metaphysics" (Epoché 15.2 [2011]: 415-34. Print), Jeffrey D. Gower analyzes Agamben in terms of 
Aristotle's pure actuality of thought thinking itself and gives an excellent account of Book Lambda, its relation to Theta, and the concept of nous. In "I Would Prefer Not To: Bartleby and the Potentiality of the Law” (Law and Critique 20.3 [2009]: 309-24. Print), Jessica Whyte gives a succinct discussion of Agamben's relation to Aristotle, potentiality, actuality, and sovereignty, but does not develop the problem of modal primacy. Rather, she focuses on Agamben's reading of Bartleby. Alberto Bertozzi's “Thoughts in Potentiality: Provisional Reflections on Agamben's Understanding of Potentiality and its Relevance for Theology and Politics" (Philosophy Today 51.3 [2007]: 290-302. Print) is a genuine contribution to Agamben's theory of modality and how it relates to Aristotle's Metaphysics Theta and the sovereign paradox, but since his essay has a twofold purpose, much of his work explores the relation between Agamben and theology rather than potentiality and sovereignty.

2/ See, for example, Agamben's The Coming Community (Trans. Michael Hardt. Minneapolis: U of Minnesota P, 1993. Print) 35 and "On What We Can Not Do" in Nudities (Trans. David Kishik and Stefan Pedatella. Stanford: Stanford UP, 2011. Print) 43-45.

$3 /$ The ambiguity of whether actuality or potentiality precedes is an antinomy that Agamben outlines in many related concepts. It appears in his concept of the "whatever" (Coming 9), in the relation between example and exception (Homo 21-23), in the concepts of "inoperativeness" and "openness," and in the "As if" and "Exigency" sections of The Time that Remains (Stanford: Stanford UP, 2005. Print), as the concept of "messianic modality" (35-39). It appears directly in "On What We Can Not Do" as the importance of resistance, in "What is Contemporary?" (Nudities 10-19) as the argument that we can perceive darkness, in his essays about Bartleby, especially "Bartleby, or On Contingency" in Potentialities (243-72), and, of course, prominently in "On Potentiality."

4/ For an analysis of Agamben's post-sovereign politics, see Sergei Prozorov's essay “The Appropriation of Abandonment: Giorgio Agamben on the State of Nature and the Political" (Continental Philosophy Review 43 [2009]: 327-53. Print).

5/ See, for example, James Gordon Finlayson's "Bare Life and Politics in Agamben's Reading of Aristotle” (The Review of Politics 72 [2010]: 97-126. Print) for the argument that the distinction between zoe and bios does not actually appear in Aristotle's Politics.

6/ In his essay "Senses of Dunamis and the Structure of Aristotle's Metaphysics $\Theta$," Andreas

Anagnostopoulos problematizes the definition of potentiality as a source of change in the actual (Phronesis 56 [2011]: 388-425. Print). Anagnostopoulos argues that while he has set up the traditional definition of potentiality as a source of change, Aristotle's intention is to define potentiality in terms of substance. While Anagnostopoulos's argument is quite persuasive and leads to a number of excellent inferences about the nature of substance, it does not disrupt the aim of my initial argument, to show that for Aristotle actuality is more primary.

7/ For a detailed account of Aristotle's objections to Megarian actualism, see Witt 18-30. Witt organizes Aristotle's objections into "the Techne Argument," "the Perception Argument," and "the Immobility Argument."

8/ Three particularly helpful studies that discuss Agamben's appropriation of Bartleby are Whyte's "I Would Prefer Not To," Alexander Cooke's "Resistance, Potentiality, and the Law: Deleuze and Agamben on Bartleby" (Angelaki 10.3 [2005]: 79-89. Print), and Prozorov's "Why Giorgio Agamben is an Optimist" (Philosophy and Social Criticism 36.9 [2010]: 1053-73. Print).

\section{WORKS CITED}

Agamben, Giorgio. Homo Sacer: Sovereign Power and Bare Life. Trans. Daniel Heller-Roazen. Stanford: Stanford UP, 1998. Print.

. “On Potentiality.” Potentialities. Trans. Daniel Heller-Roazen. Stanford: Stanford UP, 1999. 177-84. Print.

Arendt, Hannah. Eichmann in Jerusalem: A Report on the Banality of Evil. New York: Penguin, 2006. Print. 
. The Origins of Totalitarianism. New York: Harcourt, 1951. Print.

Aristotle. Metaphysics. The Complete Works of Aristotle. Vol. 2. Ed. Jonathan Barnes. Princeton: Princeton UP, 1984. 1552-728. Print.

. Politics. The Complete Works of Aristotle. Vol. 2. Ed. Jonathan Barnes. Princeton: Princeton UP, 1984. 1986-2129. Print.

De la Durantaye, Leland. Giorgio Agamben: A Critical Introduction. Stanford: Stanford UP, 2009. Print.

Makin, Stephen, trans. Aristotle Metaphysics Book $\Theta$. By Aristotle. Oxford: Clarendon, 2006. Print.

Melville, Herman. "Bartleby the Scrivener." Great Short Works of Herman Melville. New York: Harper and Row, 1969. 39-74. Print.

Schmitt, Carl. Political Theology. Trans. George Schwab. Cambridge: MIT P, 1985. Print.

Witt, Charlotte. Ways of Being: Potentiality and Actuality in Aristotle's Metaphysics. Ithaca: Cornell UP, 2003. Print.

NAHUM BROWN is a Ph.D. candidate in the philosophy department at University of Guelph. His dissertation is titled "How to Actualize the Whole Possibility: The Modality Argument in Hegel's Science of Logic." 